\title{
Isolation, Identification and Molecular Detection of Brucella abortus from Buffaloes in Gujarat, India
}

\author{
Kirit B. Patel*, H.C. Chauhan, B.K. Patel, S.S. Patel, M.D. Shrimali, J.K. Kala, S.I. Patel, \\ A.N. Modi, A.C. Patel, Manish Rajgor, M.A. Patel, M.G. Patel and B.S. Chandel \\ Department of Animal Biotechnology and Microbiology, COVSc and AH, \\ SDAU, Sardarkrushinagar-385006, Gujarat, India \\ *Corresponding author
}

\begin{tabular}{|c|c|}
\hline & A B S T R A C T \\
\hline & \multirow{7}{*}{$\begin{array}{l}\text { Brucellosis is an infectious disease, has a considerable impact on animal health as well as } \\
\text { socioeconomic impacts. It causes significant reproductive losses in sexually mature } \\
\text { animals. The present study reports the isolation, identification and molecular detection of } \\
\text { Brucella abortus. A total of } 192 \text { buffalo clinical samples were processed by cultural } \\
\text { isolation on BBL Brucella agar plate with selective antibiotic supplements and direct PCR. } \\
\text { Out of } 192 \text { clinical samples, } 7 \text { samples growth yielded on BBL Brucella agar plate and } \\
\text { identify Brucella organism by colony character, Gram's staining, MZN staining, Catalase, } \\
\text { KOH and Triple Sugar Iron Agar (TSI) test. Moreover, the confirmation of these isolate as } \\
\text { Brucella abortus was carried out by genus specific PCR using B4/B5 (223bp), species } \\
\text { specific PCR using +IS711 ( } 498 \mathrm{bp),} \mathrm{and} \mathrm{SYBR} \mathrm{green} \mathrm{based} \mathrm{real} \mathrm{time} \mathrm{PCR.} \mathrm{In} \mathrm{direct} \mathrm{PCR} \\
\text { out of } 192 \text { clinical samples, } 12 \text { samples detected positive by genus specific PCR using } \\
\text { B4/B5 ( } 223 \text { bp). Genus specific PCR positive } 12 \text { samples conform Brucella abortus by } \\
\text { species specific PCR using +IS711 ( } 498 \text { bp), and SYBR green based real time PCR. In this } \\
\text { study } 7 \text { clinical samples positive for B. abortus by culture isolation as well as direct PCR. } \\
\text { However, } 5 \text { clinical samples positive by direct PCR but could not be growth yielded on } \\
\text { BBL Brucella agar plate. }\end{array}$} \\
\hline & \\
\hline & \\
\hline $\begin{array}{l}\text { Molecular } \\
\text { detection, PCR, } \\
\text { Real time PCR. }\end{array}$ & \\
\hline Article Info & \\
\hline $\begin{array}{l}\text { Accepted: } \\
\text { 15 March } 2017 \\
\text { Available Online: } \\
10 \text { April } 2017\end{array}$ & \\
\hline & \\
\hline
\end{tabular}

\section{Introduction}

Brucellosis is caused by various species of the genus Brucella, which is the second most widely spread zoonosis worldwide (Dawood, 2008). It is one of the infectious diseases, which poses major constraint for animal production. The disease is an important public health problem in many parts of the world including India (Pal, 2007; Hadush and Pal, 2013). The disease is manifested by late term abortions, weak calves, still births, infertility and characterized mainly by placentitis, epididymitis and orchitis, with excretion of the organisms in uterine discharges and milk (England et al., 2004). In addition to its direct effects on animals, brucellosis causes economic losses through abortions, stillbirths or the death of young stock. The disease can also have a blow on exports and have negative impact on the efforts to improve breeding. Brucellosis has a considerable impact on animal and human health, as well as wide socio-economic impacts, especially in countries in which rural income relies largely on livestock breeding and dairy products 
(Maadi et al., 2011). As signs and symptoms of brucellosis are unspecific so, culture isolation andserology are necessary for diagnosis (Colmenero et al., 1996). Cultural isolation and identification of the agent is the gold standard test for Brucella diagnosis, although, limitations associated with cultural isolation and identification of the Brucella from clinical samples, the only unequivocal method for the diagnosis of brucellosis is based on the isolation of Brucella organisms (Alton et al., 1988). To surmount the problems associated with cultural isolation. Nucleic acid amplification has been explored for the rapid detection and confirmation of Brucella. A number of nucleic acid sequences have been targeted for the development of Brucella genus specific PCR assays, including 16S rRNA (Romero et al., 1995), IS711 genetic element, omp2 (Leal-Klevezas et al., 1995) and bcsp31.

\section{Materials and Methods}

\section{Collection of sample}

A total of 192various clinical samples of buffaloes were collected in BBL broth from different district of Gujarat.

\section{Isolation}

Each sample collected from an animal was separately streaked on BBL Brucella agar medium with selective antibiotic supplements and incubated at $37^{\circ} \mathrm{C}$ anaerobically in an atmosphere of 5 per cent $\mathrm{CO}_{2}$ in $\mathrm{CO}_{2}$ incubator for minimum of 15 days. The plates were observed at every 24 hours interval for the growth.

\section{Identification}

The isolates suspected to be of Brucella were subjected to Gram staining and Modified Ziehl-Neelsen (MZN) staining for confirming the purity of cultures and morphological characters, identification of Brucella organism by agglutination and biochemical test.

\section{Rapid slide agglutination test}

One drop $(0.03 \mathrm{ml})$ of known Brucella positive serum (I.V.R.I., Izatnagar) was taken on a glass slide by micropipette. A loopful culture from suspected single colony was mixed thoroughly with the spreader and then the slide was rotated for four min. The result was read immediately. Definite clumping/agglutination was considered as positive reaction, whereas no clumping/agglutination was considered as negative.

\section{Biochemical characterization of isolates}

\section{Oxidase test}

Standard oxidase discs (HiMedia Laboratories Ltd., Mumbai) containing 1\% NNN'N' tetramethyl- $\mathrm{p}$ - phenylene diamine dihydrochoride were used to perform the test. The loopful of culture from single colony was just touched on the disc. Development of blue colour within 10 seconds was considered as positive test.

\section{Catalase test}

This test was performed by taking 2-3 drops of $3 \% \mathrm{H}_{2} \mathrm{O}_{2}$ on clean grease-free sterile glass slide and single colony from BAM plate was mixed with the help of a wire loop. Immediate development of gas bubbles was considered as positive test.

\section{Triple Sugar Iron Agar (TSI) test}

In Triple Sugar Iron Agar test, a test colony was taken with a sterilized straight inoculation needle and inoculated first by 
stabbing through the center of the medium to the bottom of the tube and then streaking the surface of the agar slant. Then tube with loose cap was incubated at $37^{\circ} \mathrm{C}$ for 18 to 24 hours and observed for colour changes and gas production.

\section{Molecular detection of Brucella abortus}

\section{DNA extraction}

DNA extraction was carried out from clinical samples and colony using DN easy Blood and Tissue Kit (Qiagen) following manufacturers protocols.

Detection of Brucella abortus using genusspecific B4/B5 primer

A PCR was standardized in a total reaction volume of $25 \mu \mathrm{l}$, containing $12.5 \mu \mathrm{l}$ of $2 \mathrm{x}$ PCR Master mixture, 10 pmol of forward (5'TGG CTC GGT TGC CAA TAT CAA3') and reverse (5'CGC GCT TGC CTT TCA GGT CTG3')(Bailey et al., 1992)primers each $1 \mu \mathrm{l}$, Template DNA $2 \mu \mathrm{l}$ and nuclease free water up to $25 \mu \mathrm{l}$. The reaction was standardized in a thermal cycler (Eppendorf, Germany). with initial denaturation at $93^{\circ} \mathrm{C}$ for $5 \mathrm{~min}$, followed by 35 cycles at $90^{\circ} \mathrm{C}$ for $60 \mathrm{~s}, 64^{\circ} \mathrm{C}$ for $30 \mathrm{~s}$ and $72^{\circ} \mathrm{C}$ for $60 \mathrm{~s}$. Final extension was carried out at $72^{\circ} \mathrm{C}$ for $10 \mathrm{~min}$. The amplified product (223 bp) was electrophoresed in $2 \%$ agarose gel stained with ethidium bromide $(0.5 \mu \mathrm{g} / \mathrm{ml})$ and image was documented by gel documentation system (Mini BiS Bio Imaging System).

Detection of Brucella using species-specific B. abortus+ IS711primer

A PCR was standardized in a total reaction volume of $25 \mu \mathrm{l}$, containing $12.5 \mu \mathrm{l}$ of $2 \mathrm{x}$ PCR Master mixture, 10 pmol of forward (5' GAC GAA CGG AAT TTT TCC AAT CCC
3') and reverse (5' TGC CGA TCA CTT AAG GGC CTT CAT 3') (Bricker and Halling, 1994) primers each $1 \mu 1$, Template DNA $2 \mu 1$ and nuclease free water up to $25 \mu \mathrm{l}$. The reaction was standardized in a thermal cycler (Eppendorf, Germany). with initial denaturation at $95^{\circ} \mathrm{C}$ for $5 \mathrm{~min}$, followed by 35 cycles at $95^{\circ} \mathrm{C}$ for $90 \mathrm{~s}, 57^{\circ} \mathrm{C}$ for $120 \mathrm{~s}$ and $72^{\circ} \mathrm{C}$ for $120 \mathrm{~s}$. Final extension was carried out at $72^{\circ} \mathrm{C}$ for $5 \mathrm{~min}$. The amplified product (498 bp) was electrophoresed in $2 \%$ agarose gel stained with ethidium bromide $(0.5 \mu \mathrm{g} / \mathrm{ml})$ and image was documented by gel documentation system (Mini BiS Bio Imaging System).

SYBR green based real time PCR using $B$. abortus+ IS711primer

A PCR was standardized in a total reaction volume of $25 \mu \mathrm{l}$, containing $12.5 \mu \mathrm{l}$ of $2 \mathrm{X}$ SYBR green PCR Master mixture, $10 \mathrm{pmol}$ of forward (5' GAC GAA CGG AAT TTT TCC AAT CCC 3') and reverse (5', TGC CGA TCA CTT AAG GGC CTT CAT 3') primers each $1 \mu 1$, Template DNA $2 \mu 1$ and nuclease free water up to $25 \mu \mathrm{l}$. The reaction was standardized in a thermal cycler (Eppendorf, Germany) with initial denaturation at $95^{\circ} \mathrm{C}$ for 5 min, followed by 40 cycles at $90^{\circ} \mathrm{C}$ for 60 sec, $64^{\circ} \mathrm{C}$ for $30 \mathrm{sec}$ and $72^{\circ} \mathrm{C}$ for $60 \mathrm{sec}$ and final Melting curve analysis was carried out at $95^{\circ} \mathrm{C}$ for $15 \mathrm{sec}, 60^{\circ} \mathrm{C}$ for $1 \mathrm{~min}$ and $95^{\circ} \mathrm{C}$ for $30 \mathrm{sec}$.

\section{Results and Discussion}

\section{Isolation}

Out of 192 clinical samples, 07(3.64\%) samples produce round, glistening and smooth or mucoid colonies on Brucella agar medium (Fig. 1, Table 1). In the present finding was in agreement with earlier studies which reported $4 \%$ to $8 \%$ overall isolation rate (Ghodasara, 2008; Kanani, 2007). 
However, in contrast to these findings overall isolation rate between 20 to $39 \%$ (Das, 1990; Pal and Jain, 1985).

\section{Identification}

Morphological and staining characters of isolates

The all 7 isolates were subjected to Gram's staining and Modified Ziehl-Neelsen's (MZN) staining. In Gram's staining pink, gram negative, coccobacillary rods were observed (Fig. 2). While in MZN staining they appeared to be red coccobacillary organisms (Fig. 3). Similar morphology of organism was observed by Alton (1998), Ghodasara (2008) and Kanani (2007).

\section{Rapid slide agglutination test}

All the colonies presumed to be of Brucella organism were tested for agglutinatibility with known positive anti Brucella serum. All the isolates revealed clear agglutination, indicative of Brucella.

\section{Biochemical characterization of isolates}

All these 07 isolates gaved positive reaction in catalase (Fig. 4) and oxidase test (Fig. 5). On TSI slant, organism showed reaction as slant (yellow), butt (black) indicative as Brucella abortus (Fig. 6). Pal and Jain (1985) and Rhyan et al., (1994) reported catalase and oxidase positive for B. abortus.

Table.1 Molecular characterization of Brucella abortus from clinical samples

\begin{tabular}{|c|c|c|c|}
\hline Type of sample & $\begin{array}{l}\text { No. of } \\
\text { tested }\end{array}$ & $\begin{array}{c}\text { No. of sample } \\
\text { positive in direct } \\
\text { PCR from clinical } \\
\text { samples }\end{array}$ & $\begin{array}{l}\text { No. of isolate } \\
\text { obtained from } \\
\text { clinical samples }\end{array}$ \\
\hline Blood & 99 & 00 & 00 \\
\hline Vaginal swab & 46 & 00 & 00 \\
\hline Vaginal discharge & 05 & $\mathbf{0 3}$ & 01 \\
\hline Milk & 08 & 00 & 00 \\
\hline Placenta & 09 & $\mathbf{0 2}$ & 01 \\
\hline Placental fluid & 02 & 01 & 00 \\
\hline Hygroma fluid & 01 & 00 & 00 \\
\hline Amniotic fluid & 02 & 00 & 00 \\
\hline $\begin{array}{l}\text { Foetal intestine } \\
\text { fluid }\end{array}$ & 01 & 00 & 00 \\
\hline Foetal lung & 04 & 01 & 01 \\
\hline Foetal liver & 04 & 01 & 01 \\
\hline $\begin{array}{l}\text { Foetal stomach } \\
\text { content }\end{array}$ & 01 & 01 & 01 \\
\hline Foetal heart blood & 04 & 01 & 01 \\
\hline Cotyledon & 04 & 01 & 00 \\
\hline Foetal heart & 02 & 01 & 01 \\
\hline Total & 192 & 12 sample & 07 isolate \\
\hline
\end{tabular}


Fig.1 Growth on BBL AGAR

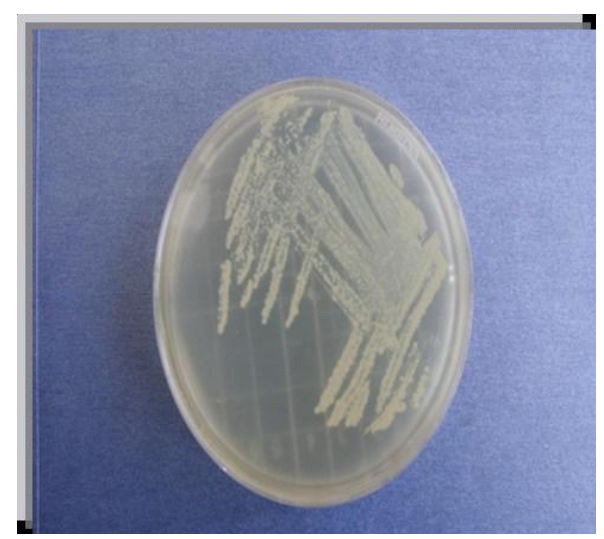

Fig.3 MZN positive

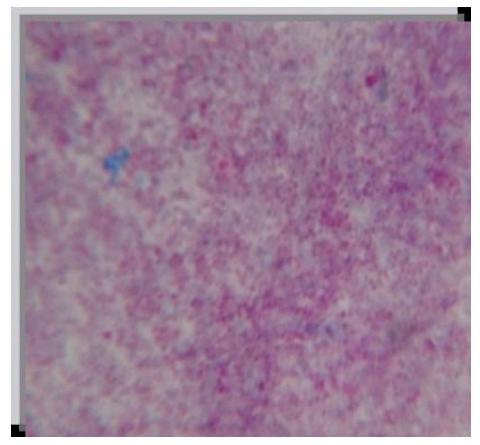

Fig.5 Oxidase test
Fig.2 Gram -ve coco bacilli

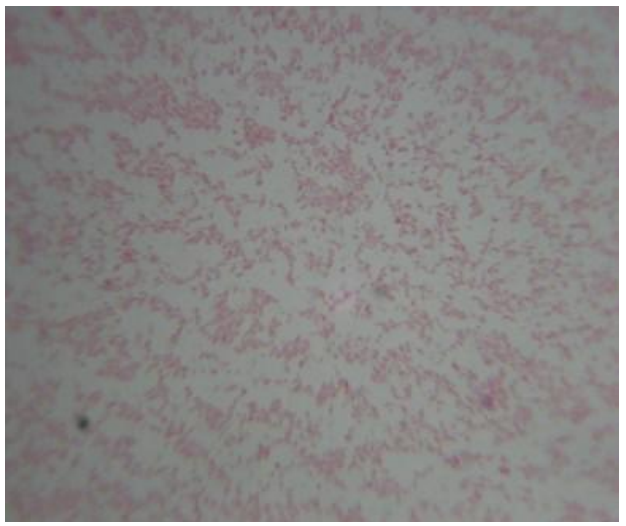

Fig.4 Catalase test

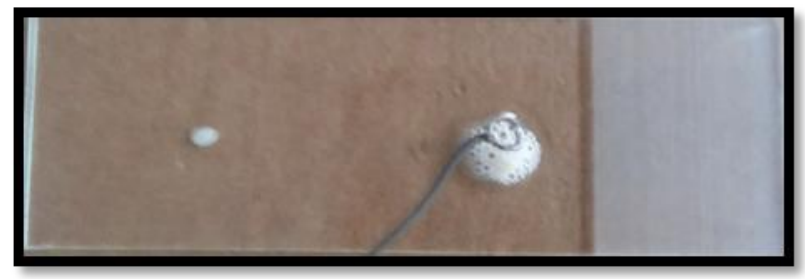

Fig.6 Triple Sugar Iron Agar (TSI) Test

\section{Control}

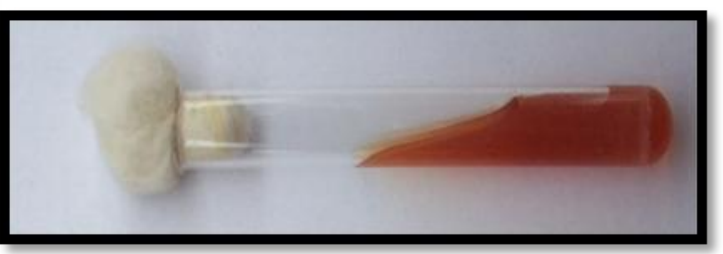

TSI: +Ve

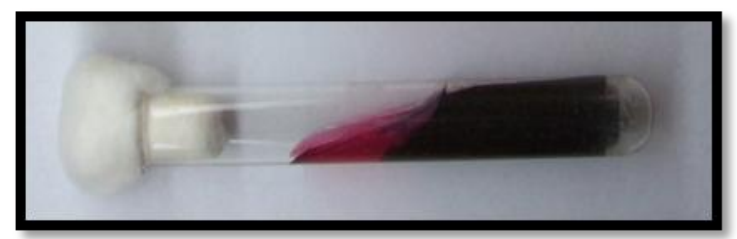


Fig.7 Agarose Gel electrophoresis of 223bp PCR products with bcsp31 primers

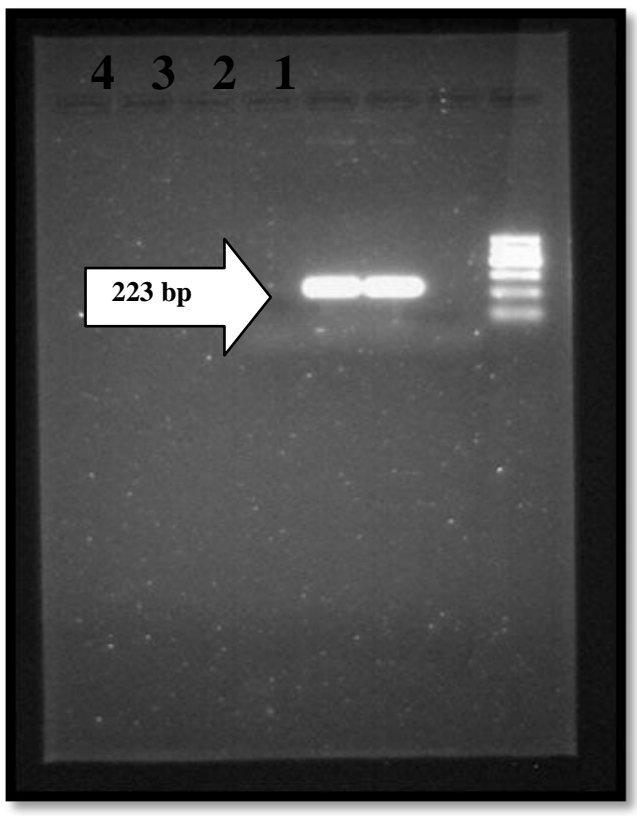

1- Ladder

2- NTC

3- Sample (positive)

4- Sample (positive)

Fig.8 Agarose Gel electrophoresis of 495 bp PCR product with primer IS711

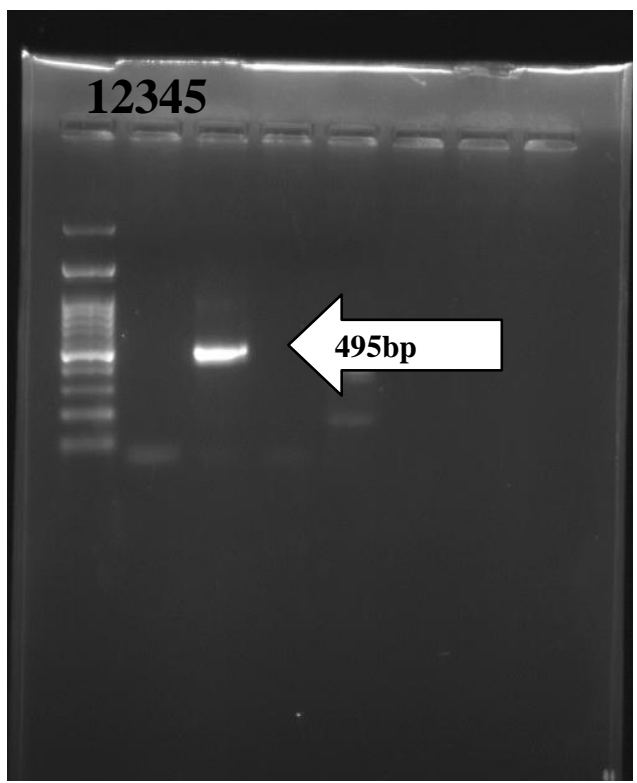

\section{1- Ladder}

2- NTC

3- Sample (positive)

4- Sample (Negative)

5- Sample (Negative) 
Fig.9 SYBR green based Real time PCR amplification plot and Melt curve

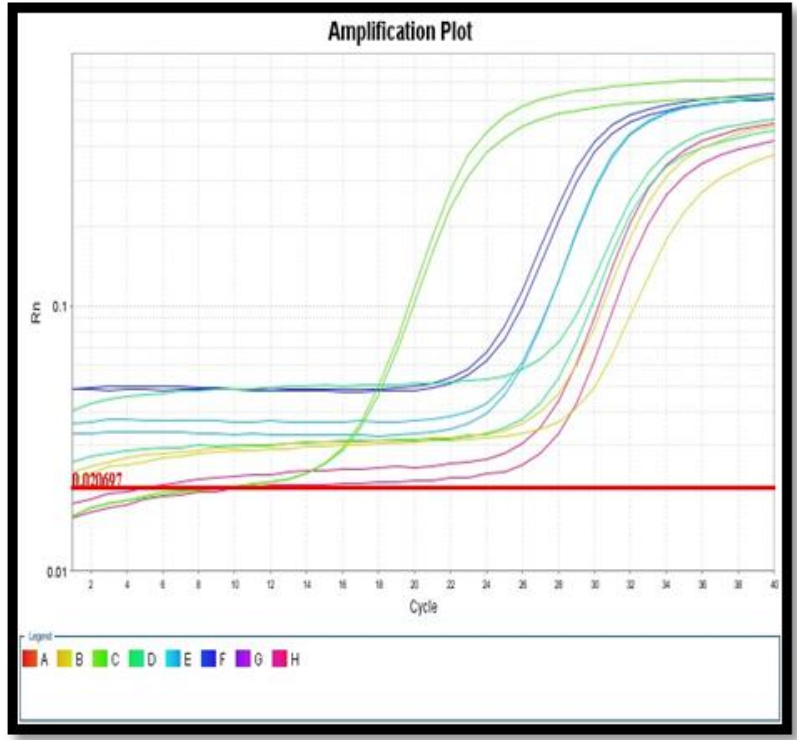

\section{Molecular detection of Brucella abortus}

In PCR study targeting 16S rRNA gene, Out of 192 clinical samples, 12 clinical samples (Table 1) and 7 culture isolated colonies were found positive to give specific amplicon of $223 \mathrm{bp}$ region of the sequence encoding a 31 $\mathrm{kDa}$ immunogenic bcsp31 by Brucella genus specific primer pairs B4/B5 (Fig. 7). All genus specific PCR positive 12 samples and 7 cultural colony yielded an amplicon of $498 \mathrm{bp}$ in +IS711 primers indicate species as Brucella abortus (Fig. 8). Similarly, Kanani (2007) and Jung et al., (1998) detection of Brucella by using bcsp31 gene based B4/B5 primer. Navarro et al., (2002) and Varasada (2003) used same primer pair for diagnosis of human brucellosis. Earlier Navarro et al., (2002), Kanani (2007) and Patel (2007) used same three primer pairs for molecular detection of Brucella abortus. Patel et al., (2015) and Karthik et al., (2014) used species specific +IS711 primers for detection of Brucella abortus and they yielding $498 \mathrm{bp}$ band when electrophoresed through 2 per cent agarose gel. SYBR green based real time PCR used for detection of Brucella abortus species

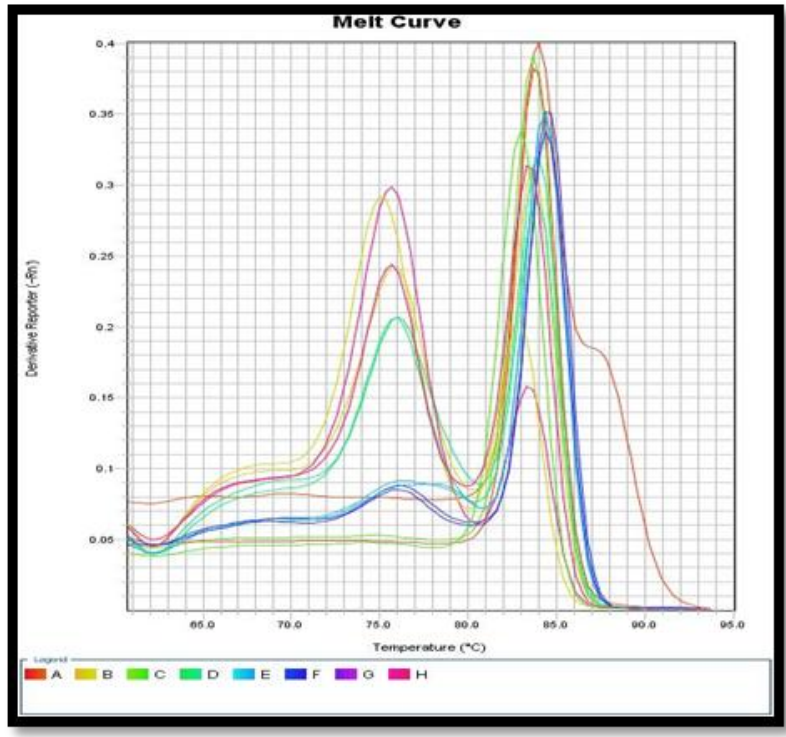

by IS711primer. All genus specific positive 12 samples and 7 cultural colony were processed by SYBR green based real time PCR. After the complete cycling parameters as described in Material and methods data analysis was done based on amplification curves obtained (Fig. 9).

The specificity of the amplified PCR products was assessed by performing a melting curve analysis. The samples which were detected positive in conventional species specific PCR also detected positive for Brucella abortus as it is matching the Tm values of the Brucella abortus control sample.

In conclusion, Molecular detection of Brucella abortus from clinical samples is more sensitive and rapid method than culture isolation. The use of the Polymerase Chain Reaction (PCR) to identify Brucella DNA at genus and species levels has becoming extended to improve diagnostic tests. The Molecular detection results showed the presence of $B$. abortus in clinical samples which is of public health importance because it is zoonotic disease. 


\section{Acknowledgement}

We are highly thankful to DBT, Govt. of India for financial assistance for the project.

\section{References}

Alton, G.G., Jones, L.M., Angus, R.D. Verger, J.M. 1998. Techniques for the brucellosis laboratory (1st ed). Institute National Recherche Agronomique (INRA), Paris.190.

Bailey, G.G., Krahn, J.B., Drasar, B.S., Stoker, N.G. 1992. Detection of Brucella melitensis and Brucella abortus by DNA amplification. J. Trop. Med. Hygiene, 95: 271-275.

Bricker and Halling.1994. Differentiation of Brucella abortus bv. 1, 2 and 4, Brucella melitensis, Brucella ovis and Brucella suis bv 1 by PCR. J. Clin. Microbiol., 32: 2660-2666.

Colmenero, J.D., Reguera, J.M., Martos, F., Sanchez-de-Mora, D., Delgado, M., Causse, M., Martin-Farfanm, A. and Juarez, C. 1996. Complications associated with Brucella melitensis infection. Med., 75: 195-211.

Das, V.M., Paranjape, V.L., Corbel, M.J. 1990. Investigation of brucellosisassociated abortion in dairy buffaloes and cows in Bombay. Indian J. Animal Sci., 60(10): 1193-1194.

Dawood, H.A. 2008. Brucellosis in camels (Camelus dromedorius) in the south province of Jordan. Am. J. Agric. Biol. Sci., 3: 623-626.

England, L., Kelly, R.D., Jones, A., MacMillan, M., Wooldridge.2004. A simulation model of brucellosis spread in British cattle under several testing regimes. Preventive Vet. Med., 63: 6373.

Ghodasara, S. 2008. Serological, cultural and molecular characterization of reproductive disorder in various animals and serodetection of Brucella antibody. An M.V.Sc. thesis submitted to A. A. U., Anand.

Hadush, A. and Pal, M. 2013. Brucellosis An infectious re-emerging bacterial zoonosis of global importance. Int. J. Livest. Res., 3: 28-34.

Jung, S.C., Jung B.Y., Woo, S.R., Cho, D.H., Kim, J.Y., Kim, W.T., Lee, J.M., Park, Y.H., Baek, B.K. 1998. Development of a PCR assay for the detection of Brucella spp. in bovine semen. Korean J. Vet. Res., 38: 345-352.

Kanani, A.N. 2007. Serological, cultural and molecular detection of Brucella infection in breeding bulls. Ph. D. thesis submitted to A. A. U., Anand.

Karthik, K., Rathore, R., Thomas, P., Arun, T.R., Viswas, K.N., Agarwal, R.K., Manjunathachar, H.V., Dhama, K. 2014. Loop-mediated isothermal amplification (LAMP) test for specific and rapid detection of Brucella abortus in cattle. Vet. Quarterly, 34(4): 174179.

Leal-Klevezas, D.S., Martinez, V.I.O., Lopez, M.A., Martinez, S.J.P. 1995. Single step PCR for detection of Brucella spp. from blood and milk of infected animals. $J$. Clin. Microbiol., 3: 3087-3090.

Maadi, H., Moharamnejad, M. and Haghi, M. 2011. Prevalence of brucellosis in cattle in Urmia. Iran. Pak. Vet. J., 31: 81-82.

Navarro, E., Escribano, J., Fernandez, J.A. and Solera, J. 2002. Comparison of three different PCR methods for detection of Brucella spp. in human blood samples. FEMS Immunol. Med. Microbiol., 34: 147-151.

Pal, M. 2007. Zoonoses. 2nd Ed. Satyam publishers. Jaipur, India, pp. 98-99.

Pal, M. and Jain, H.S. 1985. Investigation into an outbreak of abortion in buffaloes due to Brucella abortus. The Indian J. Animal Res., 6: 37-34. 
Patel, B.C., Chauhan, H.C., Chandel, B.S., Dadawala, A.I., Jain., B.K. 2015. Seroprevalence and Molecular characterization of Brucella spp. in buffalo from North Gujarat, India. Int. J. Curr. Microbiol. Appl. Sci., 4(4): 174-180.

Patel, T.J. 2007. Serological, cultural and molecular detection of Brucella infection in bovines including quantification in milk by real-time PCR. An M.V.Sc. thesis submitted to A. A. U., Anand.

Rhyan, J.C., Quinn, W.J., Stockhouse, L.S., Henderson, J.J., Ewalt, D.R., Payer, J. B., Johnson, M., Meagher, M. 1994.
Abortion caused by Brucella abortus Biovar 1 in a free-ranging bison (Bison bison) from yellow stone National Park. J. Wildl. Dis., 30(3): 445-446.

Romero, C., Pardo, M., Grillo, M.J., Diaz, R., Blasco, J.M., Lopez-Goñi, I. 1995. Evaluation of PCR and indirect enzyme-linked immunosorbent assay on milk samples for diagnosis of brucellosis in dairy cattle. J. Clin Microbiol., 33(12): 3198-3200.

Varasada, R.N. 2003. Seroprevalence of brucellosis in cattle, buffalo and human being in central Gujarat. AM.V.Sc. thesis, submitted to Gujarat Agricultural University, Sardar Krushinagar, India.

\section{How to cite this article:}

Kirit B. Pate, H.C. Chauhan, B.K. Patel, S.S. Patel, M.D. Shrimali, J.K. Kala, S.I. Patel, A.N. Modi, A.C. Patel, Manish Rajgor, M.A. Patel, M.G. Patel and Chandel, B.S. 2017. Isolation, identification and molecular detection of Brucella abortus from buffaloes in Gujarat, India. Int.J.Curr.Microbiol.App.Sci. 6(4): 1787-1795. doi: https://doi.org/10.20546/ijcmas.2017.604.214 